\title{
You must cross the bridge which spans the river of time
}

The title of my Editorial in January 1999 was 'This is your journal Europe'. In the editorial, I drew attention to the glorious but dissonant history of our wonderful Continent:

Our Continent encapsulates in glory all that is flawless in architecture, in art, in music and in literature.

But I also drew attention to our history of discord:

However, our history has been one of discord. There have been tensions resulting from language, cultural perspectives and religion.

We have been able to forgive. Archbishop Desmond Tutu has said that "Without forgiveness there is no future".

I went on to draw attention to the contribution that our Journal was intended to make:

The history of our extraordinarily beautiful Continent has been one of dissonance, but this Journal, by providing a common intellectual outlet for the anaesthetic endeavours of European anaesthetists, completes one European dream, that of unity of purpose.

Readers of our journal will have noticed the addition of the emblems of the FEEA, CENSA, ESA and UEMS, which signify that at the start of the third millennium the great European bodies of anaesthesia are drawing together - are working together. This our European journal is the visible monthly sign to anaesthetists everywhere and to all European anaesthetists that this is our voice, our journal. The Presidents and Chairmen of the organizations that have adopted the journal will soon be writing their own editorial messages to its readers. The journal welcomes the new associations and co-operation with them for this co-operation is the future. Welcome.

My own time as editor in chief, January 1994 to December 1999, is now at an end. It was for me a great privilege to be entrusted with the responsibility of guiding the journal, but the time seems to have passed in an instant. While I have made many new friends, I know I have upset some others. I apologize to those who may have felt aggrieved - I don't like editors-in-chief either, who would when after a protracted conception and a hard labour, one's finest work of science is judged by them to be unsuitable to breathe immediately or indeed at all. These were the hard times. I have enjoyed being forced to keep upto-date, to watch anaesthesia advance as new knowledge is interpreted and applied. I thank all the editors and the referees for their generous help, and of course my deputy editor-in-chief Professor Brian Pollard who looked after the editorials. I owe a great debt to the journal secretary, Mrs Kathy Dimelow. She was always present and always in charge. No journal can survive without a secretary and we authors and editors have shared the best!

The old order now changes and a new Editor will bring more change and improvement. I take this opportunity to welcome and introduce my successor and friend, Professor Anthony (Tony) Adams. As he sets sail as captain, may I wish him a fair wind. May this ship of progress sail on, ever growing in stature, and may he enjoy the privilege of working with you, the readers and the authors, as much as I have done. I wish the editorial team, authors, prospective authors and readers good reading with good luck and success for the future.

At this moment in time, as we cross from the 20th to the 21st century, those of Christian, or other, or of no spiritual belief, all recognise that this moment is an internationally identified and recognised measure of the time that has elapsed since the birth of Jesus Christ. This is a time of celebration for Christians. I therefore conclude my editorship by extracting some passages from His Holiness Pope John Paul II's address to the United Nationals General Assembly on Thursday, October 5, 1995 in New York City, NY, USA. This address projects the rights, the unity and the peace that we, Christians and others, all seek and to which 
we hope this journal contributes - a unity of friendship and of purpose.

Ladies and gentlemen! On the threshold of a new millennium, we are witnessing an extraordinary global acceleration of that quest for freedom which is one of the great dynamics of human history. This phenomenon is not limited to any one part of the world; nor is it the expression of any single culture. Men and women throughout the world, even when threatened by violence, have taken the risk of freedom, asking to be given a place in social, political, and economic life which is commensurate with their dignity as free human beings. This universal longing for freedom is truly one of the distinguishing marks of our time.

It is important for us to grasp what might be called the inner structure of this world-wide movement. It is precisely its global character which offers us its first and fundamental 'key' and confirms that there are indeed universal human rights, rooted in the nature of the person, rights which reflect the objective and inviolable demands of a universal moral law.

These are not abstract points; rather, these rights tell us something important about the actual life of every individual and of every social group. They also remind us that we do not live in an irrational or meaningless world. On the contrary, there is a moral logic which is built into human life and which makes possible dialogue between individuals and peoples. If we want a century of violent coercion to be succeeded by a century of persuasion, we must find a way to discuss the human future intelligibly. The universal moral law written on the human heart is precisely that kind of 'grammar' which is needed if the world is to engage this discussion of its future.

The moral dynamics of this universal quest for freedom clearly appeared in Central and Eastern Europe during the nonviolent revolutions of 1989. Unfolding in specific times and places, those historical events nonetheless taught a lesson which goes far beyond a specific geographical location. For the nonviolent revolutions of 1989 demonstrated that the quest for freedom cannot be suppressed. It arises from a recognition of the inestimable dignity and value of the human person, and it cannot fail to be accompanied by a commitment on behalf of the human person. Modern totalitarianism has been, first and foremost, an assault on the dignity of the person, an assault which has gone even to the point of denying the inalienable value of the individual's life.

The revolutions of 1989 were made possible by the commitment of brave men and women inspired by a different, and ultimately more profound and powerful, vision: the vision of man as a creature of intelligence and free will, immersed in a mystery which transcends his own being and endowed with the ability to reflect and the ability to choose, and thus capable of wisdom and virtue. A decisive factor in the success of those nonviolent revolutions was the experience of social solidarity: in the face of regimes backed by the power of propaganda and terror, that solidarity was the moral core of the power of the powerless, a beacon of hope and an enduring reminder that it is possible for man's historical journey to follow a path which is true to the finest aspirations of the human spirit. .. .

History shows that in extreme circumstances (such as those which occurred in the land where I was born) it is precisely its culture that enables a nation to survive the loss of political and economic independence. Every nation therefore has also the right to shape its life according to its own traditions, excluding of course, every abuse of basic human rights and in particular the oppression of minorities. Every nation has the right to build its future by providing an appropriate education for the younger generations. ...

The fact of 'difference', and the reality of 'the other', can sometimes be felt as a burden, or even as a threat. Amplified by historic grievances and exacerbated by the manipulations of the unscrupulous, and the fear of 'difference' can lead to a denial of the very humanity of 'the other': with the result that people fall into a cycle of violence in which no one is spared, not even the children. ...

From bitter experience, then, we know that the fear of 'difference', especially when it expresses itself in a narrow and exclusive nationalism which denies any rights to 'the other', can lead to a true nightmare 
of violence and terror. And yet if we make the effort to look at matters objectively, we can see that, transcending all the differences which distinguish individuals and peoples, there is a fundamental commonality.

For different cultures are but different ways of facing the question of the meaning of personal existence. And it is precisely here that we find one source of the respect which is due to every culture and every nation: every culture is an effort to ponder the mystery of the world and in particular of the human person. It is a way of giving expression to the transcendent dimension of human life. The heart of every culture is its approach to the greatest of all mysteries: the mystery of God.

Our respect for the culture of others is therefore rooted in our respect for each community's attempt to answer the question of human life. And here we can see how important it is to safeguard the fundamental right to freedom or religion and freedom of conscience, as the cornerstones of the structure of human rights and the foundation of every truly free society. No one is permitted to suppress those rights by using coercive power to impose an answer to the mystery of man. ...

Ladies and gentlemen! Freedom is the measure of man's dignity and greatness. Living the freedom sought by individuals and peoples is a great challenge to man's spiritual growth and to the moral vitality of nations. The basic question which we must all face today is the responsible use of freedom in both its personal and social dimensions. Our reflection must turn then to the question of the moral structure of freedom, which is the inner architecture of the culture of freedom. Freedom is not simply the absence of tyranny or oppression. Nor is freedom a license to do whatever we like. Freedom has an inner 'logic' which distinguishes it and ennobles it. Freedom is ordered to the truth, and is fulfilled in man's quest for truth and in man's living in the truth. ...

In order to ensure that the new millennium now approaching will witness a new flourishing of the human spirit, mediated through an authentic culture of freedom, men and women must learn to conquer fear. We must learn not to be afraid, we must rediscover a spirit of hope and a spirit of trust. Hope is not empty optimism springing from a naïve confidence that the future will necessarily be better than the past. Hope and trust are the premise of responsible activity and are nurtured in that inner sanctuary of conscience where 'man is alone with God' and he thus perceives that he is not alone amid the enigmas of existence, for he is surrounded by the love of the Creator! ...

We must overcome our fear of the future. But we will not be able to overcome it completely unless we do so together. The 'answer' to that fear is neither coercion or repression, nor the imposition of one social 'model' on the entire world. The answer to the fear which darkens human existence at the end of the 20th century is the common effort to build the civilization of love, founded on the universal values of peace, solidarity, justice, and liberty. And the 'soul' of the civilization of love is the culture of freedom: the freedom of individuals and the freedom of nations, lived in self-giving solidarity and responsibility.

We must not be afraid of the future. We must not be afraid of man. It is no accident that we are here. Each and every human person has been created in the 'image and likeness' of the One who is the origin of all that is. We have within us the capacities for wisdom and virtue. With these gifts, and with the help of God's grace, we can build in the next century and the next millennium a civilization worthy of the human person, a true culture of freedom. We can and must do so! And in doing so, we shall see the tears of this century have prepared the ground for a new springtime of the human spirit. ...

Permission has been granted by Monsignor Pedro López Quintana to use extracts of Pope John Paul III's Address to the United Nations General Assembly.

T. E. J. Healy, MD, LLM, MSc, FRCA Department of Anaesthesia, Manchester Royal Infirmary, Manchester M13 9WL, England, UK 